\title{
Review of CILIP Conference Brighton, 12-13 July 2016
}

\author{
Lyn Denny
}

\begin{abstract}
A review of the CILIP Conference 2016 by the Library and Information Research Group bursary winner. The report focuses on four key areas that stood out for the author: everyday innovation; the library as a safe place; conducting library and information research; and networking for the new professional.
\end{abstract}

\section{Introduction}

The CILIP Conference aims to appeal to all sectors by "bringing the information world together" (CILIP, 2016, 1) and I was impressed by the varied yet cohesive programme. The themes this year were Managing Information, Everyday Innovation and Using Technology. The keynotes, parallel sessions and breakout talks were complemented by less formal Fringe discussions and a Your Career strand. A vibrant exhibition hall was in operation for the duration of the conference with representatives from library and information suppliers and CILIP Special Interest Groups.

As a newly qualified professional, this was my first CILIP Conference. My aim in attending was to focus on library and information research; how it can be conducted, used and shared. I was particularly excited about the Everyday Innovation theme and how it might be conceptualised by the everyday use of library research. I was also interested in the networking opportunities to share enthusiasm and ideas with fellow professionals.

This report will focus on four key areas that stood out for me over the course of the two days: everyday innovation; the library as a safe place; conducting library and information research; and networking for the new professional.

\section{Everyday innovation}

Most of the talks I attended touched on the theme of Everyday Innovation, but two in particular were memorable. The first was a keynote titled 'The opportunities and challenges of open data' given by Sir Nigel Shadbolt, Professor

\section{Author}

Lyn Denny is a subject librarian at Manchester Metropolitan University.

Email: 1.denny@mmu.ac.uk

Received 04 August 2016

Accepted 10 August 2016 
of Computer Science at University of Oxford and Principal of Jesus College. Sir Shadbolt gave a fascinating presentation on the development of open data and how it is currently being used by organisations in innovative ways. For example, he mentioned how Transport for London makes data available openly so that software developers can create useful travel applications for customers. In Sir Shadbolt's own words, "...open data is only part of the story; the real magic is the innovation that comes from it". This keynote inspired me to think about how I share data, information and knowledge with colleagues; but also to consider ways we might do more with data at a practical level in my organisation.

'Using a business approach to developing a library service' presented by Neil Infield, Manager of the Business and IP Centre at the British Library was lively and informative. Infield explained that by conducting research to find out what services their customers needed, many of whom were entrepreneurs, the library service began to identify with being a start-up itself and applied many business strategies they had learned to their own way of working. For example, when they had an idea for a new product or service they would test it first with a sample of customers, before launching anything new on a bigger scale. This talk has encouraged me to think about the wealth of research I have access to in my role as a subject librarian, not just focussing on libraries, but research examining practices in other industries such as retail; and how I might use this research to develop ideas and improve my own practice as an information professional.

\section{The library as a safe space}

A theme that recurred for me during the two-day event was the concept of the library as a safe place. In his moving keynote 'What we did in Ferguson: a wartsand-all telling of stories' Scott Bonner, director of Ferguson public library, told the story of how the library became a place of comfort and safety for the local community during the months of protests and riots that followed the shooting of African American Michael Brown by a white police officer in 2014. He described how this was accomplished through partnerships with other organisations and a wide programme of events and initiatives. For example, the library partnered with a local school to provide all day care for children whose families were left without childcare when the schools delayed opening following the summer vacation. Bonner's account of the role his library played during this period of fear and unrest in his locale was, for me, perfectly encapsulated by a sign he displayed in the library which read: "During difficult times, the library is a quiet oasis where we can catch our breath, learn and think about what to do next".

In her parallel session 'The fences are up here: what is the role of our libraries in supporting and protecting our communities from a rising mental health crisis?' poet and educator Becci Louise reminded us of the rising mental health crisis in this country and implored us librarians and our libraries to help. She spoke about how words and conversations are a powerful healer and can undo stigma attached to mental illness. She stated that libraries are the ideal place in which to have these conversations since we collect words! Becci Louise gave some practical suggestions of how we can do this: by connecting readers with fiction and nonfiction characters who have a mental health condition themselves; by connecting 
readers with texts that can help them to help themselves; and by just being there and having conversations with our customers.

Through both these talks, and others I encountered at the CILIP Conference, I learned practical ways to provide support to library users in times of need.

However, I also learned that the concept of the library as a safe place can mean different things to different people at different times and would be a fascinating topic to research.

\section{Conducting library and information research}

There was plenty of inspiration for other topics to research at the CILIP Conference. Furthermore, two other talks that I attended provided practical guidance in conducting library and information research. In her talk titled 'The outcomes of reading for pleasure and empowerment' Laura Venning from The Reading Agency outlined how she drew on existing research into the benefits of reading for pleasure to create a Reading Outcomes Framework and Evaluation Toolkit. Information professionals are encouraged to use the dual purpose tool to advocate for reading for pleasure initiatives, but also to conduct our own evaluations of activities. The toolkit will be made available on the Reading Agency's website in September 2016 and I look forward to assessing how I might use it to measure impact in my volunteer role in a primary school library.

A highlight for me at the CILIP Conference was the Your Career strand 'Shouting about the value of our skills' in which we heard from Dr Alison Brettle, Reader in Evidence Based Practice and Director of Post Graduate Research in the School of Nursing, Midwifery and Social Work Research, University of Salford. Dr Brettle spoke about how she conducted a systematic scoping review of existing evidence of the benefits that library, information and knowledge (LIK) professionals bring to their place of employment (Brettle and Maden, 2015). She described details of the research method she used, for example the process of study selection and some inclusion / exclusion criteria. It was remarkable to hear how 7188 citations had been reduced to 135 studies to be reviewed. This research has clear uses in terms of advocating for our profession in a variety of settings, but this presentation was also important to encourage more research into the impact of the LIK profession. Dr Brettle stated that there is a need for more UK based research and that researchers would do well to consider borrowing research methodologies from sectors other than their own, since different sectors tend to favour different methodologies.

\section{Networking for the new professional}

The CILIP Conference is a wonderful way to engage in networking opportunities and I was delighted to catch up with friends and to make new contacts. On the first morning I learned that perusing the exhibition stands and talking to the exhibitors is a great way to get background knowledge on library and information service context, particularly outside my own sector. For instance, it was interesting to talk to many of the library management software companies about their products and customers. The Special Interest Groups area of the main exhibition hall was particularly useful to find out about the varied activities of our 
profession and to consider how to engage further in continuing professional development. The well-attended Party on the Pier provided a good opportunity for networking. I also found it lucrative to follow the \#CILIPConf16 hashtag throughout the conference and discovered new people to engage with on Twitter.

\section{Conclusion}

I was fortunate to receive a bursary from the Library and Information Research Group to attend the CILIP Conference and I would recommend applying for bursaries to anyone who would like to attend the conference in the future. In addition to the obvious financial assistance, there are other benefits. Having agreed to tweet from the conference and to write this report about my experience, I felt that my mind was focussed during the many presentations I attended. My notes were themed towards library and information research as a result, but were also more developed and considered.

I thoroughly enjoyed my first CILIP Conference and I am already looking forward to next year's event in Manchester. The task now is to follow Tom Forrest's advice from the Fringe 'Discussion session: Thinking through everyday innovation, using technology and managing information', which was to take something I learned at the CILIP Conference 2016 and to do something with it.

\section{References}

Brettle, A. and Maden, M. (2015) What evidence is there to support the employment of trained and professionally registered library, information and knowledge workers? A systematic scoping review of the evidence [online]. URL: http://www.cilip.org.uk/sites/default/files/documents/value of trained lik worke rs_final_211215.pdf [Accessed 02.08.16]

CILIP (2016) CILIP 2016 Conference 12-13 July Brighton: Bringing the information world together. London: CILIP Events.

\section{Open access and copyright}

Library and Information Research is an open access journal. A freely available copy of this paper may be downloaded from the journal's website: http://www.lirgjournal.org.uk.

Copyright and associated moral rights in works published in Library and Information Research are retained by the author(s) but this paper may be used freely, with proper attribution, in educational and other non-commercial settings. 